\title{
Hyper-intensive farming of white shrimp Litopenaeus vannamei in a freshwater tank under semi-controlled conditions (Decapoda: Penaeidae)
}

\section{A.A. Ortega-Salas and L. A. Rendón M.}

Unidad Académica Mazatlán, Instituto de Ciencias del Mar y Limnología, UNAM. Calzada Joel M. Camarena s/n, Mazatlán 82040, Sinaloa, México. Apdo.Post.811; ortsal@ola.icmyl.unam.mx

Received 3-XII-2012 Corrected 15-I-2013 Accepted 29-I-2013

\begin{abstract}
Developing shrimp to a commercial size in a confined freshwater space is important because it saves food and because predators and diseases are avoided. Our study was conducted to calculate the growth of white shrimp Litopenaeus vannamei by hyper-intensive farming in fresh water from 0,5 to $5 \%$ and under semi-controlled conditions. We seeded at a density of 563 postlarvae $/ \mathrm{m}^{3}$ or $\mathrm{m}^{2}$ during the first cycle and 400 postlarvae $/ \mathrm{m}^{3}$ in the second cycle in an outdoor pond of $6 \mathrm{~m}^{3}$ or $\mathrm{m}^{2}$ covered with a mesh. Aeration was constant, they were fed Daphnia magna during the first two weeks and then camaronina pellets containing $35 \%$ protein, in food baskets, as demanded. The temperature ranged from 22,3 to $31,3^{\circ} \mathrm{C}$, $\mathrm{pH}$ between 7,5 and 8,7 , the oxygen was $4,26 \pm 1,43 \mathrm{mg} / \mathrm{L}$; the ponds were cleaned of debris every other day, and water was changed according to a program. The food conversion factor (FCA) was 1:1,1. The shrimp were measured weekly to calculate growth using the Bertalanffy model. Survival in the first cycle was 88,1 and $95,8 \%$ for the second cycle. Population parameters by maximum likelihood method of the first cycle were $k=0,0957, L_{\infty}=146,98$ and $t_{0}=-$ 0,93 ; in the second cycle $k=0,0172, L_{\infty}=367,82$ and $t_{0}=-4,60$. The results indicate rapid growth during the first ten weeks. Biomass was obtained from $26 \mathrm{~kg}$ for the first cycle and $16 \mathrm{~kg}$ for the second cycle.
\end{abstract}

\section{KEY WORDS}

Growth, density, survival, biomass, semi-controlled conditions.

\section{RESUMEN}

Es importante que en un espacio reducido se pueda desarrollar camarón a un tamaño comercial en agua dulce con alta densidad, se ahorra en comida, se evitan depredadores y enfermedades. El estudio se realizó con el fin de calcular el crecimiento del camarón blanco Litopenaeus vannamei mediante un cultivo hiper-intensivo en agua dulce 0,5 a $5 \%$ o y bajo condiciones semi-controladas. Se sembraron a una densidad de 563 postlarvas $/ \mathrm{m}^{3}$ o $\mathrm{m}^{2}$ durante el primer ciclo y de 400 postlarvas $/ \mathrm{m}^{3}$ en el segundo ciclo en un estanque de $6 \mathrm{~m}^{3} \mathrm{o} \mathrm{m}^{2}$ al aire libre, se mantuvo el estanque tapado con una malla, la aireación fue constante, se les alimentó con Daphnia magna durante las dos primeras semanas y luego con pellets de camaronina con $35 \%$ de proteína, en canastas de alimentación, como lo demandaban. La temperatura varió entre 22,3 a $31,3^{\circ} \mathrm{C}$, el $\mathrm{pH}$ entre 7,5 y 8,7 , el oxígeno tuvo $4,26 \pm 1,43 \mathrm{mg} / \mathrm{L}$; los estanques se sifonearon de detritus cada tercer día, y se hicieron recambios del volumen de agua de acuerdo a un programa. El factor de conversión alimenticia (FCA) fue de 1:1.1. Los camarones se midieron en longitud y peso semanalmente para calcular el crecimiento, utilizando el modelo de Bertalanffy. La sobrevivencia en el primer ciclo fue 88,1 y $95,8 \%$ para el segundo ciclo. Los parámetros poblacionales por el método de máxima verosimilitud del primer ciclo fueron $\mathrm{k}=0,0957$, $L_{\infty}=146,98$ y $t_{0}=-0,93$; en el segundo ciclo $k=0,0172, L_{\infty}=367,82$ y $\mathrm{t}_{0}=-4,60$. Los resultados indican un crecimiento acelerado durante las primeras 10 semanas. Se obtuvo una biomasa de $26 \mathrm{~kg}$ para el primer ciclo y $16 \mathrm{~kg}$ para el segundo ciclo.

\section{PALABRAS CLAVE}

Crecimiento, densidad, sobrevivencia, biomasa, condiciones semicontroladas. 
The heavy demands on the market and the pressure of disease have led to new alternatives for shrimp farming. Intensively cultivated farms and hyper-intensive have a significant advantage, do not occupy large tracts of land and produce up to 5 times more than what other systems produce the same culture period. On the other hand, in Mexico less than $1 \%$ shrimp that are grown is intensive home and worldwide is less than 5\% (Olguín Pineda, 2006), this percentage is a very small part, which has been commissioned to grow in fresh water.

Shrimp farming in fresh water is relatively new, and there are few crops grown in the country. During its life cycle, the shrimp are always subject to environmental conditions; therefore, agencies must maintain the dynamic equilibrium. The physiological state of organisms is a critical factor for assessing the degree of influence of environment on the biology of the organism (Alpuche, Pereyra \& Agundis, 2005).

Given the lack of progress in the implementation of management techniques that increase production levels to a point in which the business back to profitability, some producers started testing intensive crops in what is called highlands. These systems consist of small ponds (less than or equal to $1 \mathrm{Ha}$ ) and the water comes from wells with salinity less than 7\%o (Limsuwan, 2005).

Both the excess salinity as the introduction to aquatic diluted shrimp forces to conduct a process called osmoregulation, which is to maintain the balance between the salts inside and outside his body, introduction to media where salt ion concentration is higher than the body itself causes consume much energy and keeps growing at the same rate as do those that grow in water less salty.

The study was conducted to calculate the growth of white shrimp Litopenaeus vannamei by hyper-intensive farming in freshwater from 0,5 to $5 \%$ and under semicontrolled conditions

\section{METHODOLOGY}

The work was conducted at the facilities of Mazatlan Academic Unit of the Institute of Marine Sciences and Limnology, UNAM (Northwest of Mexico). The planting of the first cycle began May 11 and ended on August 4, 2007 (summer). The seeded of the second cycle began on 12 September to 5 December 2007 (autumn).

Fresh water comes directly from municipal drinking water is piped through underground pipes connected to a system of silica sand filter, which go directly to a reservoir of $5000 \mathrm{~L}$ capacity. Hence pipe through $2^{\prime \prime}$ is supply tanks of the experimental area.
The air system has two electric blowers, one with capacity of $2 \mathrm{HP}$ and another with $1 \mathrm{HP}$. Aeration is supplied through PVC pipe 0,5 inches in diameter. For the measurement of ammonia $\left(\mathrm{NH}_{3}-\mathrm{N}\right)$ used a brand Ammonia Photometer $\mathrm{HI} 93715$ HANNA model with measurement range of 0,00 to $9,99 \mathrm{mg} / \mathrm{L}( \pm 0,05 \mathrm{mg} / \mathrm{L})$. The $\mathrm{pH}$ was measured with an error of 0,1 potentiometers Mark Hanna calibrated to buffer $\mathrm{pH}=7$ for oxygen measurement using the $\mathrm{YSI} 55$ portable oximeter with a range of 0 to $20 \mathrm{mg} / \mathrm{L}( \pm 0,25 \mathrm{mg} / \mathrm{L})$, the same that allows measurements of salinity with a precision of $0,1 \%$ and a range of 0 to $80 \%$. We used a mercury thermometer mark Broken, -20 to $110^{\circ} \mathrm{C}\left( \pm 1^{\circ} \mathrm{C}\right)$.

The culture of white shrimp $L$. vannamei ponds was carried out in $1,65 \times 3,66 \times 1,0 \mathrm{~m}$ deep $\left(6,03 \mathrm{~m}^{3}\right)$. The culture is hyper-intensive, were seeded at a rate of $563 \mathrm{PL} / \mathrm{m}^{3}$ in the first cycle and $400 \mathrm{PL} / \mathrm{m}^{3}$ in the second cycle. The pond was covered with a mosquito net. The postlarvae were acquired in laboratories located in "Aguaverde" Aqua Pacific, Rosario, Sinaloa. In his transfer were used plastic bags and coolers, which were given pure oxygen and live food, in this case Artemia. The postlarvae were received in a $75 \mathrm{~L}$ tank for acclimatization, they decreased the initial salinity of $35 \%$ o to $50 \%$ with fresh water the first day, so on every day, the second day was with $18 \%$, the third day was with $9 \%$, on the fourth day, was with 2,2\%o (Ortega-Salas, Castro \& Núñez-Pastén, 2005), were fed D. magna and commercial food brand Joma 1000 F-4 foil and initiator, according to Montealegre (2001). The size of the postlarvae PL12 and PL14 ranged from the first cycle and between PL18 and PL20 for the second cycle.

The culture media for microalgae were previously washed, filled with fresh water, disinfected with commercial sodium hypochlorite $6 \%(0,2 \mathrm{~mL} / \mathrm{L})$ for twentyfour hours before being used, then neutralized with sodium thiosulfate (50ppm) and with continuous aeration through plastic hoses. Before inoculating the microalgae in exponential phase of the production chain, the water was fertilized using the culture method F (Guillard, 1973).

The postlarvae directly counted with the use of a mesh network of 300 microns against aphida, the organisms caught with the net were put into a white dish for direct counting and then deposited in a bucket for transport to the ponds.

After the first week for the first cycle and the second week for the second cycle, they began to supply pet food in feeding trays as they demanded. Performance food is supplied with 35\% LD brand NASSA protein, two portions in the morning and one in the afternoon, there will be checked every day to add or decrease the amount of food. Samples were taken seven days to make measurements of length and weight. 
The length measurement is made with a millimeter ruler and Ohaus digital scale for weighing GT480. They also include dead organisms that may come out in the trays.

During the growing season is very important to siphoning the bottom of the pond with a hose diameter of 0,5 inches, to avoid accumulation of detritus. A basket is placed in the output mosquito net to prevent some shrimp could escape down the drain at the time of siphoning.

We also carried out the water changes from the second week of initiation of the culture at a rate of $30 \%$ every seven days during the first 3 weeks of culture, then $40-50 \%$ every 5 days for the next three weeks, from $50-60 \%$ every 4 days for the next three weeks and $60-90 \%$ in recent weeks every three to five days.

Once the information is collected statistical package used Excel Statistics and the statistical program version 6.0 (StatSoft Inc., Tulsa, OK). Was plotted and calculated the length-weight relationship and growth in length and weight over time (Figs. 1-3), using the equation of von Bertalanffy growth in weeks, $L(t)=L \infty\left(1-e^{-k(t-t o)}\right)$ where $\mathrm{L}_{(\mathrm{t})}=$ total length prediction at time $\mathrm{t}, \mathrm{L} \infty=$ theoretically maximum length $\mathrm{k}=$ instantaneous growth rate; $\mathrm{t}_{0}=$ theoretical time of onset of growth. We also performed the estimation of these population parameters by the method of maximum likelihood (L) (Hilborn \& Mangel, 1997), we applied the curve matching test using the F statistic with $3(\mathrm{~K}-1)$ and $(\mathrm{N}-3 . \mathrm{K})$ Degrees of freedom to make comparisons between the growths in length by weeks of two growing cycles.

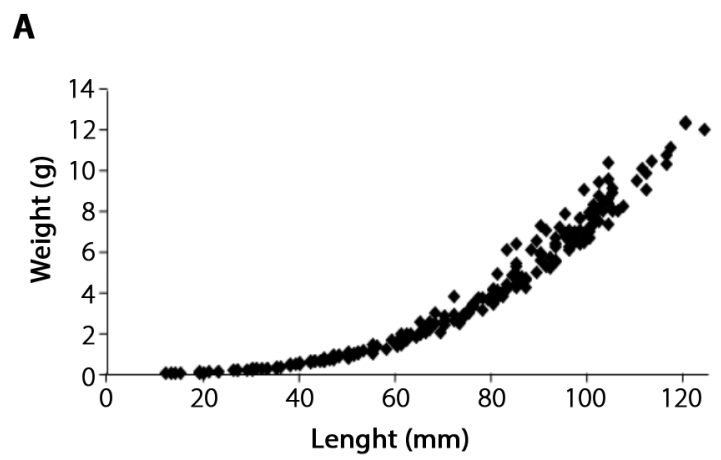

\section{RESULTS}

In the pond the temperature varied from 22,3 to $31,3{ }^{\circ} \mathrm{C}$ in two cycles, the lowest was in the second season (autumn). The $\mathrm{pH}$ had a mean of $8,04 \pm 0,22$ in the first cycle and $8,44 \pm 0,34$ for the second cycle, the most important effect of $\mathrm{pH}$ on the ponds, is its effect on the ionization of ammonium, high values reduce the ionization of ammonium $\mathrm{NH}_{4}$ to $\mathrm{NH}_{3}$ (Hopkins et al., 1993). Dissolved oxygen is considered the variable quality of water, more critically, the lowest measurement was $1,9 \mathrm{mg} / \mathrm{L}$, towards the end of culture, but showed a mean of $5,14 \pm 1,28 \mathrm{mg} / \mathrm{L}$ in the first cycle and 4,43 $\pm 0,93 \mathrm{mg} / \mathrm{L}$ for the second cycle. Salinity plays an important role in osmoregulation and ions (SainzCarrion \& Urias-Cuadras, 2001), in our case do not have problem, both cycles ranged from 0,5 to $5 \%$ o $(2,56 \pm 1,16)$. Ammonium, variations in $\mathrm{N}-\mathrm{NH}_{3}$ in $\mathrm{mg} / \mathrm{L}$ had a variation of 0,45 to $1,24 \mathrm{mg} / \mathrm{L}(0,85 \pm 0,18 \mathrm{mg} / \mathrm{L})$. In the second cycle ranged from 0,05 to $2,96 \mathrm{mg} / \mathrm{L}(1,11 \pm 0,79 \mathrm{mg} / \mathrm{L})$.

The weight-length was performed and expressed in Fig. 1, we applied a one-way ANOVA with significance of $95 \%$, to determine if there was an effect between the dependent variable in this case the weight and be independent the length of an $F(1751,251)$ for the first cycle and $F$ $(2299,373)$ for the second cycle, indicating that the length affects the weight. The equation of the weight-length relationship used to calculate the weight in the calculated time length in time with the von Bertalanffy equation. It was found that the residues were normal, independent, zero mean and constant variance, obtaining for the first

B

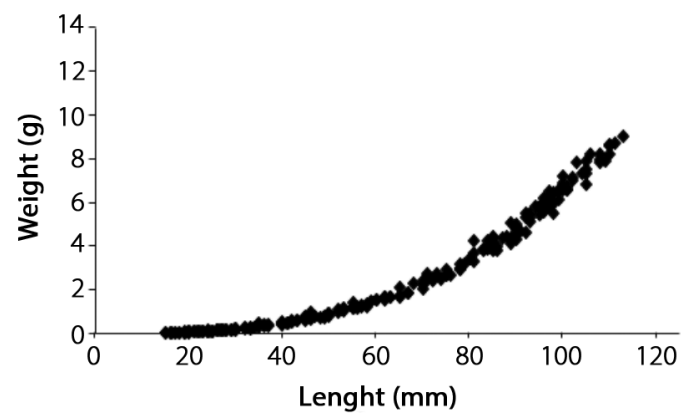

FIG.1. (A) Weight-length relationship first cycle: $P=0,000009 L 2,9586, R^{2}=0,994$. (B) Weight-length relationship second cycle: $P=0,00001 L 2,8725, R^{2}=0,996$. 
cycle, the following equation: $P=9 E-05^{L 2.9586}$, with an $R^{2}$ of 0,994 , and for the second cycle: $P=1 E-05 L^{2.8625}$, with an $R^{2}$ of 0,996 . With the growth model of von Bertalanffy and tested with negative response surfaces of the natural logarithm of maximum likelihood, the growth parameters obtained for the first cycle: $L \infty=146,98, K=0,0957$ and $\mathrm{t}_{0}=-0,9304$ and for the second cycle: $\mathrm{L} \infty=367,82, \mathrm{~K}=0,0172$ and $\mathrm{t}_{0}=-4605$ (Fig.2).

Performing the test of matching curves (Fig. 3), grown in both agencies work cycles as a single population and the growth curves are combined and we get: $L \infty=261,35, k=0,0406, t_{0}=-0,9635$ and, when values are substituted in the equation of curves coinciding $F$, the results are $F=12,0477$ with a $P=0,0001$, these results indicate that both growth curves do not differ in growth, given the results accepted the null hypothesis and conclude that no statistically significant differences between growth curves.
The average length of postlarvae used for the development of the first cycle was $7,5 \pm 0,5 \mathrm{~mm}$, while for the second cycle; the average length was $19,25 \mathrm{~mm}$. In the first cycle were sown 3400 in $6 \mathrm{~m}^{2}$, at the end remain 2995 with a survival rate of $88,1 \%$, the average weight per week was $0,0255 \mathrm{~g}$ to obtain the average weight of $8,78 \mathrm{~g}$ final and the percentage of weekly food was of $6,68 \%$ to $3,00 \%$, the feed conversion factor was of $1: 0,5$ to $1: 1,4$, total biomass was $26,3 \mathrm{~kg}$ harvested. In the second cycle twelve weeks of culture were seeded 2400 organisms in $6 \mathrm{~m}^{2}$, at the end remain 2300 with a survival rate of $95,8 \%$, the average weight per week was $0,0631 \mathrm{~g}$ of until a weight final average of $7,67 \mathrm{~g}$, the percentage of weekly food was of $15,97 \%$ to $2,26 \%$, the feed conversion factor was of $1: 1,1$ to $1: 1,2$, total biomass was $16,6 \mathrm{~kg}$ harvested. The difference in weight, length and biomass in the first round for the second, probably was the number of postlarvae at the beginning and the temperature was higher in the first cycle.
A

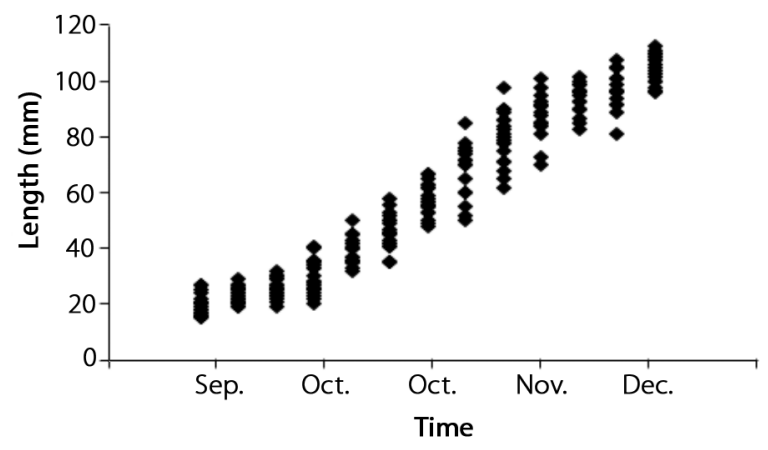

C

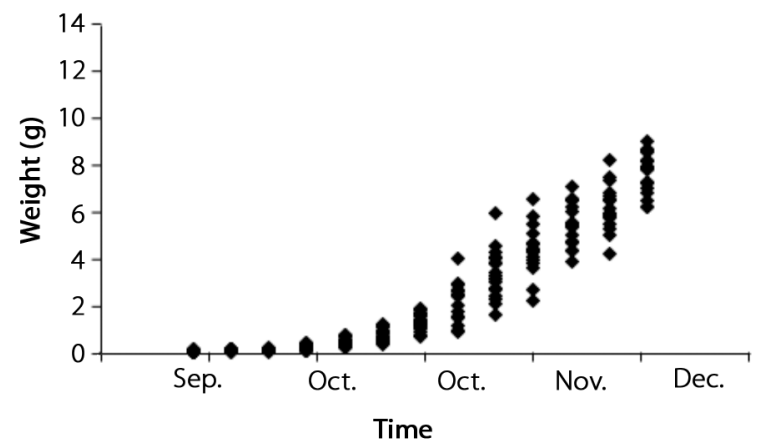

B

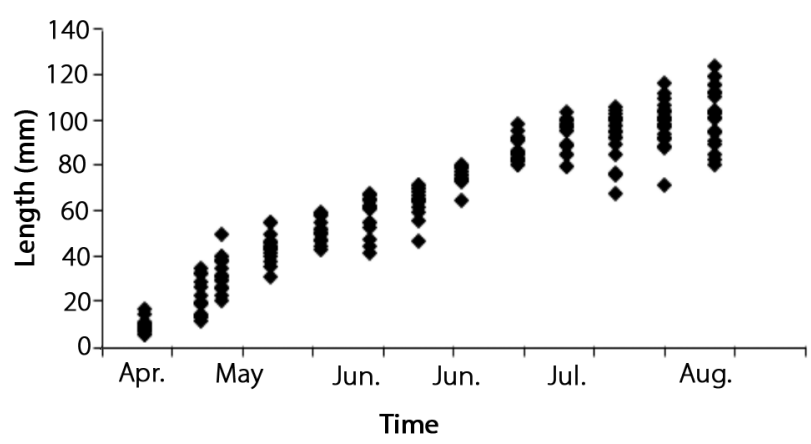

D

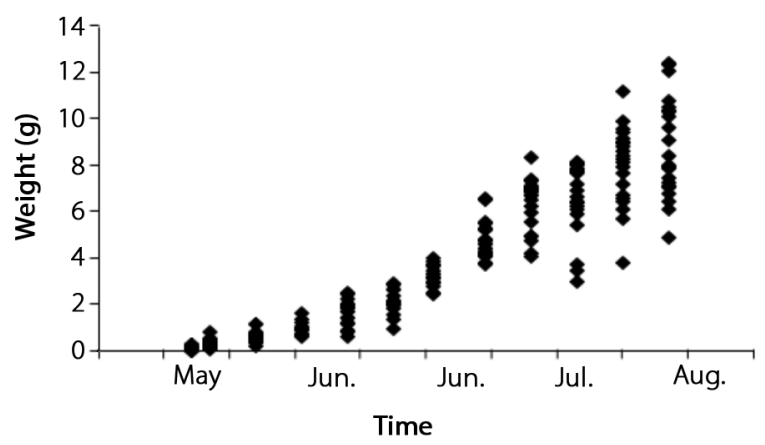

FIG. 2. (A) Growth in the first cycle length: $k=0,0957, L \infty=46,98$ y $t_{0}=-0,93$, (B) Growth in the second cycle weight: $k=0,0172$, $L_{\infty}=367,82, t_{0}=-4,60$, (C) Growth in the first cycle weight: $P_{t}=0,000009, L_{t} 2,9586, R^{2}=0,994$, (D) Growth in the second cycle weight: $P_{t}=0,00001$ Lt 2,8725, $R^{2}=0,996$. 


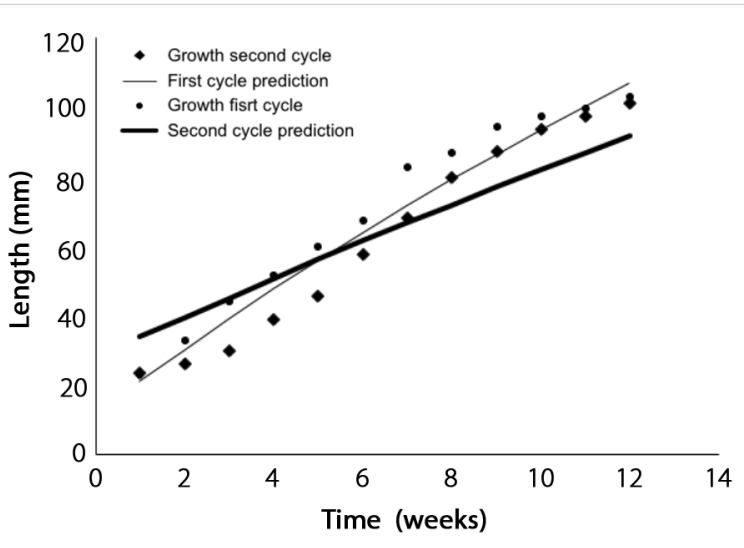

FIG. 3. Growth curves of von Bertalanffy applying the matching test for growth of organisms in the first round against the second cycle, the points represent the first cycle and the diamonds the second cycle.

We applied the maximum likelihood method to find the parameters of von Bertalanffy growth; this method is more efficient because it minimizes the response surface in search of values.

\section{DISCUSSION}

Boyd (1989) considers that the species commonly develop in ponds grow best in the range of 23 to $3^{\circ} \mathrm{C}$. Other authors such as Bassanesi-Poli (1987), Ruiz-Fernandez (1995), indicate temperatures in semi-extensive rustic ponds similar to those mentioned above. Garza-Bravo (1998) concludes that the best growth of L. vannamei is given in a combination at $30^{\circ} \mathrm{C}$ and salinity $15 \%$. In this study, salinity ranged from 0,5 to $5 \%$ o $(2,56 \pm 1,16 \mathrm{SD})$, the temperatures recorded during the first cycle coincide with those of the authors, mainly due to the entrance of the rainy season in the region represents an increase in room temperature, otherwise it goes in the cultivation of the second cycle as they have decreases in temperatures of up to $8^{\circ} \mathrm{C}$ with temperatures reaching up to $22^{\circ} \mathrm{C}$, this for the entrance of the dry season in the region, which is attributed to a smaller increase in length and weight than those recorded in the first cycle. The two growth factors that are molting frequency and increase in size by moulting (Hartnoll, 1982), and temperature is the factor that most affects the duration of the cycle of change, when it increases, the cycle becomes shorter.
Tsai (1990), considers that lower levels of $\mathrm{pH}$ to 4,8 and greater than 10,6, are lethal to penaeids, in the present study, the $\mathrm{pH}$ ranged between 7,5 and 8,7 is considered acceptable.

Oxygen is the variable most limiting, Boyd and Fast (1992) recommend that the best growth of penaeids is obtained dissolved oxygen concentrations of $3,5 \mathrm{mg} / \mathrm{L}$ of saturation values less than $1 \mathrm{mg} / \mathrm{L}$ can be lethal, in the this study, 1,9mg/L was introduced toward the end of cultivation, but showed a mean of $5,14 \pm 1,28 \mathrm{mg} / \mathrm{L}$. According to Boyd (1989), the toxicity of ammonia affects rather low rates of growth rather than mortality, in this work, there were higher values of ammonia in the second cycle.

Water shrimp requires specific concentrations of major anions: sulphates and chlorides, bicarbonates, and major cations: calcium, magnesium, potassium and sodium (Boyd, Thunjai \& Boonyaratpalin, 2002). In a dilute environment, organisms must solve two problems, the water entering the body and loss of body salts, as well as internal environment excretion of metabolic end products to counteract these effects, organisms are able to change the gill permeability, also generate a lot of urination in order to conserve diluted salts useful and regulate internal osmotic pressure. Useful ions are lost in the urine, is reabsorbed through the gills where the active transport of salts, the epithelium to the interstitial fluid and the gills, is favored by ion exchange pump sodium / potassium (Newell, 1976). In the present study salinity ranged $2,56 \pm 1,16$ so there was no problem of anions or cations.

In the studies conducted for shrimp growth in culture media at low salinities, Boyd et al. (2002) states that the inland shrimp farming has been a common practice in countries like Thailand. They started testing intensive crops. These systems consist of small ponds (less than or equal to $1 \mathrm{Ha}$ ) and the water comes from wells with salinity lower than 7\%o (Limsuwan, 2001). Bray, Lawrence \& Leung (1994), conducted an experiment to evaluate the adaptability of the white shrimp at salinities of from $5-49 \mathrm{~g} / \mathrm{L}$, where best results were obtained between 5 and 15g/L. Balbi, Rosas, Velásquez, Cabrera \& Maneiro (2005), obtained in a study of acclimation of postlarvae to low salinity, the postlarvae (PL12 and PL19) of L. vannamei were successfully acclimated to well water salinity of $3 \%$.

Zarain-Herzberg (2007), reports floating cage densities of 700 organisms $/ \mathrm{m}^{2}$ in Sinaloa, Mexico for a phase of prebreeding or pre-fattening, later moving to a density of 200 organisms $/ \mathrm{m}^{2}$. In this work we opted for two seeding densities without pre-breeding phase or pre-fattening only had a period of acclimation, which was 550 organisms/ $\mathrm{m}^{3}$ for the first cycle and 400 organisms $/ \mathrm{m}^{3}$ for the second cycle. In Thailand, have yields of 15 ton/ha, in this work, if 
one could extrapolate per hectare, in both cycles ranged from 29,4 to 45,6 ton/Ha. In a farm intensive cultivation of shrimp in Nayarit with stocking densities of 80 postlarvas/ $\mathrm{m}^{2}$ survival were obtained with yields of $80,55 \% 18,04 \mathrm{ton} /$ Ha (Olguin-Pineda, 2006).

\section{ACKNOWLEDGEMENTS}

We thank the technical support of A. Nuñez P., M. H. Castro and S. Rendón R.

\section{REFERENCES}

Alpuche J, Pereyra, A. \& Agundis, C. (2005). Respuestas bioquímicas de camarones marinos a factores ambientales. Revista Electrónica de Veterinaria REDVET-ISSN, 6(5), 1695-7504.

Balbi, F., Rosas, J., Velásquez, A., Cabrera, T. \& Maneiro, C. (2005). Aclimatación a baja salinidad de postlarvas de camarón marino Litopenaeus vannamei (Boone, 1931) provenientes de dos criaderos comerciales. Rev. Biol. Mar. Ocean, 40(2), 109-115.

Bassanesi-Poli, A.T. (1987). Análisis de un cultivo de camarón blanco (Penaeus vannamei, Boone) en estanques rústicos en San Blas, Nayarit, México. Tesis doctoral, UACP y P-CCH, UNAM, México.

Boyd, C.E. (1989). Water quality management and aeration in shrimp farming. Fisheries and Allied Aquacultures Departmental Series No. 2, Alabama Agricultural Experiment Station, Auburn University, Alabama. USA.

Boyd, C. \& Fast, A.W. (1992). Pond monitoring and management. In Marine shrimp culture: principles and practices. Developments in aquaculture and fisheries science, volume 23. The Netherlands: Els. Sc. Pub. B.V.

Boyd C., Thunjai, T. \& Boonyaratpalin, M. (2002). Dissolved salts in water for inland low salinity shrimp culture. Glob. Aquac. Adv. 5(3), 40-45.

Bray W.A, Lawrence, A.L. \& Leung Trujillo, J. (1994). The effect of salinity on growth and survival of Penaeus vannamei with observations on the interaction of IHHN virus and salinity. Aquac, 122(2-3), 133-146.

Garza-Bravo, F.J. (1998). Efectos de la temperatura y salinidad sobre el crecimiento consume de alimento y sobrevivencia de postlarvas de Litopenaues vannamei (Boone, 1931). Tesis de licenciatura. FACIMAR. UAS. Mazatlán, México.
Guillard, R.R.L. (1973). Methods for microflagellates and nannoplakton . In Handbook of phycological methods - culture methods and growth measurements. New York, USA: Cambridge Univ. Press.

Hartnoll, R.C. (1982). Growth. In The biology of Crustacea, Vol. 2, Embryology, morphology, and genetics. New York, USA: Academic Press.

Hilborn, R.R. \& Mangel, M. (1997). The ecological detective. Confrontating models with data. USA: Priceton University Press.

Hopkins, J., Stephen, R.,Hamilton, D., Sandifer, P.A., Browdy, C.L. \& Stokes, A.D. (1993). Effect of water exchange rate on production, water quality, effluent characteristics and nitrogen budgets of intensive shrimp ponds. Jour. Worl. Aquac-Soc., 24(3).

Limsuwan, C. (2005). Cultivo intensivo del camarón blanco. (Resumen de visitas y conferencias a camaroneras del Perú en Noviembre 2005). Octubre - Diciembre 2005.

Montealegre, J. (2001). Protocolo de larvicultura para Litopenaeus vannamei. Taller "Cultivo de camarones para inversionistas. Experiencia venezolana: 8Tm/ha". Maracaibo, Venezuela, 8-9 Junio de 2001.

Newell, R.C. 1976. Adaptation to environment: essays on the physiology of marine animals. Universidad de California, USA: Butterworths.

Olguín-Pineda, M. (2006). Entrevista. In Industria Acuícola. Mayo, 2(4), 16-19.

Ortega-Salas, A., Castro, M.H. \& Núñez-Pastén, A. (2005). Cultivo hiperintensivo de camarón blanco en estanques de agua dulce. Segundo Foro Internacional de Acuicultura. 1- de Diciembre. Expo Forum, Hermosillo, Sonora, México.

Ruíz-Fernández, A.C. (1995). Calidad de agua de cuatro granjas camaronícolas en el noroeste de México: Estudio comparativo de las características físicas, químicas y de contribución orgánica de aguas de ingreso y egreso. Tesis de Maestría. ICMyL-UNAM. Mazatlán, México.

Sainz-Carrion, L. \& Urias-Cuadras, J.A. (2001). Determinación de las variables fisicoquímicas relacionadas con el crecimiento de Litopenaeus vannamei en un ciclo de cultivo semi-intensivo. Tesis de licenciatura. Biólogo acuicultor. FACIMAR. UAS. Mazatlán, México.

Tsai, C.K. (1990). Water quality management. In Proc. Southeast Asia Shrimp Farm Management Workshop, Philippines, Indonesia, Thailand, 26 July-11 August 1989 American Soybean Association, Singapore.

Zarain-Herzberg, M. (2007). Jaulas flotantes: una alternativa de cultivo. Industria Acuícola, 2, 17-19. 